\title{
Optimizing in vitro factors for improvement of shoot proliferation of 'Flordaguard' peach rootstock
}

\author{
Valmor João Bianchi ${ }^{*}$ (D), Cristina Weiser Ritterbusch ${ }^{1}$ (D), \\ Simone Ribeiro Lucho' ${ }^{1}$, Elizete Beatriz Radmann ${ }^{2}$ (i) \\ Department of Botany, Federal University of Pelotas, Pelotas, RS, Brazil \\ ${ }^{2}$ Federal University of Pampa, Itaqui, RS, Brazil \\ *Corresponding author: valmorjb@yahoo.com
}

Recebido em 13.III.2020

Aceito em 18.V.2021

DOI 10.21826/2446-82312021v76e2021011

ABSTRACT -'Flordaguard' has shown great potential as a standard rootstock for peach. The aim of this study was to examine the influence of Murashige \& Skoog (MS) medium and modified MS- $-1 / 2 \mathrm{~N}$ medium (half Nitrogen content), explant type and angle orientation on the culture medium, as well as 6-benzylaminopurine (BAP) concentrations on in vitro shoot proliferation in 'Flordaguard' rootstock. Explants cultured in MS-1/2N medium showed higher averages for number of lateral shoots and elongated shoots. The maximum average length of lateral shoots was obtained using doublephase medium. The $3.0 \mathrm{mg} \mathrm{L}^{-1} \mathrm{BAP}$ induced the highest number of lateral shoots per explant $(3.38 \pm 0.57)$. Whereas the higher number of lateral shoots elongated $(1.75 \pm 0.10 \mathrm{~cm})$ occurred at concentrations until $2.0 \mathrm{mg} \mathrm{L}^{-1}$ BAP. The study corroborated the importance of a $50 \%$ reduction in both $\mathrm{NH}_{4} \mathrm{NO}_{3}$ and $\mathrm{KNO}_{3}$ content in the cultured medium to improvein vitro propagation of 'Flordaguard' peach rootstock.

Keywords: BAP, explant orientation, medium composition, Prunus

RESUMO - Otimização de fatores in vitro para aumentar a proliferação de brotações do porta-enxerto de pessegueiro 'Flordaguard'. 'Flordaguard' mostrou grande potencial para ser usada como porta-enxerto padrão para pessegueiro. O objetivo deste estudo foi examinar a influência da concentração do meio Murashige \& Skoog (MS) e meio MS modificado (MS- $1 / 2 \mathrm{~N}$ - contendo metade da concentração de Nitrogênio), tipo de explante e ângulo de orientação do explante no meio de cultura, bem como de 6-benzilaminopurina (BAP) na proliferação de brotações in vitro no porta-enxerto 'Flordaguard'. Explantes cultivados em meio MS-1/2N apresentaram as maiores médias para número de brotações laterais e de brotações alongadas. O maior comprimento médio de brotações laterais foi obtido usando meio dupla-fase. A concentração de $3,0 \mathrm{mg} \mathrm{L}^{-1}$ de BAP induziu o maior número médio de brotações laterais por explante $(3,38 \pm 0,57)$. Enquanto que o maior número de brotações alongadas $(1,75 \pm 0,10$ $\mathrm{cm}$ ) ocorreu em até $2,0 \mathrm{mg} \mathrm{L}^{-1}$ BAP. O estudo comprova a importância de reduzir em $50 \%$ as concentrações de $\mathrm{NH}_{4} \mathrm{NO}_{3}$ e $\mathrm{KNO}_{3}$ para a propagação in vitro do porta-enxerto 'Flordaguard'.

Palavras-chave: BAP, composição do meio, Prunus, tipo do explante

\section{INTRODUCTION}

The Prunus genus includes some of the most important temperate fruit species (Abbasi et al. 2019). Amongst these species, the peach (Prunus persica (L.) Batsch) is the main stone fruit produced both in Brazil and throughout the world (Pei et al. 2019). When renewing orchards or increasing areas of cultivation, the genetic material and the system used to produce high quality peach plants is extremely important for the establishment of productive orchards. In Brazil peach trees are traditionally produced by grafting the scions cultivar onto seed-derived rootstocks (mainly from pits supplied by the processing industry), resulting in heterogenous plants with a lack of genetic identity of the root system (Mayer et al. 2017), so clonal propagation is a more desirable method.
It is well documented that rootstocks are responsible for absorbing water and nutrients, providing resistance to soil pests, and influencing tolerance to environmental problems (Abbasi et al. 2019). Research has already developed rootstocks with diverse genetic origins, with potential for use in replanting sites, better graft compatibility, resistante to biotic and abiotic stress, and capable of inducing different levels of vigour and yield on the scion cultivars, and other characteristics (Loreti \& Massai 1999; Reighard \& Loreti 2008). The use of rootstocks incorporating the maximum number of desirable characteristics is important, so is defining the usefulness of a rootstock; the success of a fruit orchard depends on the use of high quality rootstocks. According to Sherman et al. (1991) 'Flordaguard' is a rootstock cultivar that shows many desirable characteristics, such as good graft compatibility with peach scion cultivars, 
resistance to root-knot nematodes (Meloidogyne javanica and $M$. incognita), and featuring adaptation to Brazilian weather conditions.

In the nursery industry, vegetative propagation of peach rootstocks by cuttings is limited, especially because of the low rates of rooting success and plant survival (Duval et al. 2013). Additionally, such methods of plant propagation can significantly contribute to the dissemination of pathogens, which negatively affect plant development and orchard yield. Thus, compared to the cuttings method, in vitro propagation has major advantages, since it can be carried out throughout the year and allows greater control of propagation conditions (Kassaye \& Bekele 2015, Hassan et al. 2018, Silvestri et al. 2019; Abbasi et al. 2019).

A high rate of shoot proliferation in vitro is a prerequisite for clonal propagation of plants at large scale and there are several factors that can determine success (Arab et al. 2014, Silva et al. 2016). Some of these factors are related to the formulation and consistency of the medium, the choice of plant growth regulators (PGR) and their concentrations, as well as the type of explant used (Hassan et al. 2018). According to Phillips \& Garda (2019) choice of the proper culture medium is one of the first factor to be considered, due to the important role of the mineral components in the multiplication process. For several species MS medium (Murashige \& Skoog 1962) is most-commonly used, but for Prunus spp. dilutions of this medium, or even other formulations containing lower concentrations of salts, are recommended, depending on the particular species or cultivar (Silva et al. 2016).

The addition of PGR to the in vitro culture medium is extremely important, and cytokinins are generally indispensable as they are responsible for inducing axillary shoots and overcoming apical dominance. However a decrease in multiplication potential (shoot induction and elongation) has been observed in different species and cultivars of Prunus spp., when the explants were subcultured for several times on medium of unchanged hormonal and salt composition (Radmann et al. 2009a, 2011). The explant angle from the horizontal on the culture medium, the type of explant, and other additional treatments, such as use of activated charcoal (AC) (Hassan et al. 2018), may also influence in vitro multiplication.

Another factor that can contribute to increasing the multiplication rate and growth of explants is the use of 'double-phase' medium, as described for species of the genus Pyrus spp. (Rodríguez et al. 1991, Kadota et al. 2001, Moraes et al. 2004) and Ananas sp. (ScherwinskiPereira et al. 2012). This method consists of adding a liquid medium composed of the same as the semi-solid phase, but without gelling agent, overlapping the semisolid medium containing the explantes (Kadota et al. 2001, Scherwinski-Pereira et al. 2012) in order to supply additional nutrients and plant growth regulators more easily for the explants, compared to semi-solid culture medium (Machado et al. 2004).

In Brazil the rootstocks currently used by most nurserymen in the majority of cases is a mixture of scion cultivars seeds without genetic identity and often susceptible to root-knot nematodes. The 'Flordaguard' rootstock presents itself as a more promising alternative for use in Brazilian conditions. Although there are several studies in tissue culture of Prunus, due to the high degree of variability in the results it is necessary to verify the optimal cultivation conditions for each species and/or cultivar (Radmann et al. 2011, Arab et al. 2014). Therefore, with this study we have assessed the influence of salt concentration in MS medium, explant type and its insertion angle on the culture medium, as well as BAP concentration on the in vitro shoot proliferation of 'Flordaguard' rootstock.

\section{MATERIAL AND METHODS}

\section{Plant material and in vitro culture of 'Flordaguard' peach rootstocks}

'Flordaguard' peach rootstock was developed at the University of Florida (United States of America), and it is derived from the sixth generation descendant of 'Chico' $(P$. persica) x P. davidiana (Carr.) Franch C-26712 (Sherman et al. 1991). The plant material used in the study comes from 2-year old mother plants maintained in a greenhouse according to Radmann et al. (2011). Actively growing shoots harvested in mid-spring were disinfested in our laboratory, as described by Viganó et al. (2007). After disinfection, they were cut into single-node (1.0 cm lenth) and used as explants, and than vertically inoculated in test tubes (25 x $150 \mathrm{~mm})$ containing $10 \mathrm{~mL}$ of aseptic semi-solid MS medium (Murashige \& Skoog 1962), without PGRs. Thereafter, the explants were placed in a growthroom at $25^{\circ} \mathrm{C} \pm 2{ }^{\circ} \mathrm{C}$, in the dark for seven days, and then taken to a 16-hour photoperiod and a light flux density of $48 \mu \mathrm{mol} \mathrm{m}{ }^{-2}$ $\mathrm{s}^{-1}$, a condition being used in all other stages of the cultures.

All media used along the different experiments were full strength MS or modified MS medium (MS- $1 / 2 \mathrm{~N}-$ containing half the total $\mathrm{NH}_{4} \mathrm{NO}_{3}$ and $\mathrm{KNO}_{3}$ ), supplemented with mio-inositol $\left(100 \mathrm{mg} \mathrm{L}^{-1}\right)$, sucrose $\left(30 \mathrm{~g} \mathrm{~L}^{-1}\right)$, at $\mathrm{pH}$ 5.8 , with ( $7 \mathrm{~g} \mathrm{~L}^{-1}$ agar) or no gelling agent, and changing PGR composition. The initial explants were growing in test tubes for 35 days. The aseptic shoots formed from the axillary buds of each growing explant were removed from the nodal segment and then proliferated on $\mathrm{MS}-1 / 2 \mathrm{~N}$ medium, supplemented as above plus BAP $\left(4 \mathrm{mg} \mathrm{L}^{-1}\right)$ and IBA (0.01 $\left.\mathrm{mg} \mathrm{L}^{-1}\right)$ according to Radmann et al. (2011), in order to increase the amount of shoots for carrying out the ulterior experiments. Before starting each experiment, shoots were subcultured for 15 days on semi-solid MS- $1 / 2 \mathrm{~N}$ medium (Murashige \& Skoog 1962) without PGR, except for Experiments 2 and 3, which were a continuation of Experiment 1. 


\section{Effect of medium culture composition on shoot proliferation}

Experiment 1. The apical portion of shoots $(1.0 \mathrm{~cm}$, previously subcultured in semi-solid MS- $1 / 2 \mathrm{~N}$, without PGR) were used as explants and placed into flasks containing $40 \mathrm{~mL}$ of semi-solid MS and MS- $1 / 2 \mathrm{~N}$, both supplemented with $4 \mathrm{mg} \mathrm{L}^{-1}$ 6-benzylaminopurine (BAP) and $0.01 \mathrm{mg} \mathrm{L}^{-1}$ indolebutyric acid (IBA) according to Radmann et al. (2011). The flasks were taken to the growing room for four weeks, when the number of lateral shoots sprouted per explant was evaluated.

Experiment 2. After the evaluation of the first experiment under aseptic conditions, the explants were transferred to new flasks containing the flesh semi-solid MS and N-1/2N medium, and supplemented with BAP $\left(0.5 \mathrm{mg} \mathrm{L}^{-1}\right)$, IBA $\left(0.01 \mathrm{mg} \mathrm{L}^{-1}\right)$, in order to evaluate the effect of reduction on BAP dose over the shoot elongation. After four weeks of culture, the data were recorded as: number of lateral shoots, number of lateral shoots elongated, and average length of lateral shoots $(\mathrm{cm})$ per explant.

Experiment 3. After the evaluation of the second experiment under aseptic conditions, the explants were again subcultured to new flasks containing the flesh semisolid MS and $\mathrm{N}^{-1} / 2 \mathrm{~N}$ medium as described for Experiment 2, plus $1.0 \mathrm{~g} \mathrm{~L}^{-1} \mathrm{AC}+1.0 \mathrm{mg} \mathrm{L}^{-1}$ gibberellic acid $\left(\mathrm{GA}_{3}\right)$. Additionally, we prepared a liquid culture medium with the same composition (without gelling agent, BAP and IBA), but containing $1.0 \mathrm{~g} \mathrm{~L}^{-1} \mathrm{AC}+1.0 \mathrm{mg} \mathrm{L}^{-1} \mathrm{GA}_{3}$, which was directly poured over the respective semi-solid culture media (10 $\mathrm{mL}$ per flask), in order to produce a double-phase medium in $50 \%$ of the flasks containing the different MS and MS- $-1 / 2 \mathrm{~N}$ medium. The experiment therefore comprised the following treatments: $\mathrm{T}_{1}-$ semisolid MS- $1 / 2 \mathrm{~N}+$ liquid MS- $1 / 2 \mathrm{~N}$ medium containing $\mathrm{AC}$ and $\mathrm{GA}_{3} ; \mathrm{T}_{2}-$ semi-solid MS-1/2N; $\mathrm{T}_{3}-$ semi-solid MS + liquid $\mathrm{MS}$ medium containing $\mathrm{AC}$ and $\mathrm{GA}_{3}$; and $\mathrm{T}_{4}$ - semi-solid MS. The same data as in Experiment 2 were recorded after 20 days of culture.

\section{Effect of explant type and its angle of inoculation on shoot induction and proliferation}

Experiment 4. Shoots previously subcultured in semi-solid MS- $1 / 2 \mathrm{~N}$, without PGR) were used as the explantes $(1.0 \mathrm{~cm})$, with or without the apical portion (apical meristem) of the shoot, that were inoculated attwo differente angle $\left(45^{\circ}\right.$ and $90^{\circ}$ ) on the semi-solid MS- $1 / 2 \mathrm{~N}$ medium and supplemented with $3.0 \mathrm{mg} \mathrm{L}^{-1} \mathrm{BAP}$, and $0.01 \mathrm{mg} \mathrm{L}^{-1} \mathrm{IBA}$. Thirty days later, $10 \mathrm{~mL}$ of the liquid $\mathrm{MS}-1 / 2 \mathrm{~N}$ medium (as described in Experiment 3) were added to each flask, creating the double-phase medium. After 20 days, the same data as in Experiment 2 were recorded.

\section{Effect of BAP concentration on shoot induction and proliferation}

Experiment 5. Shoots previously subcultured in semi-solid MS- $1 / 2 \mathrm{~N}$ (without PGR) were used as the explantes (1.0 $\mathrm{cm}$ ), without the apical portion of the shoot. They were inoculated on semi-solid MS- $1 / 2 \mathrm{~N}$ medium supplemented with different concentrations of $\mathrm{BAP}(0.0,0.5,1.0,2.0,3.0$ $\left.\mathrm{mg} \mathrm{L}^{-1}\right)$. Thirty days later, $10 \mathrm{~mL}$ of the same liquid MS$1 / 2 \mathrm{~N}$ medium (as described in Experiment 3) were added to each flask, creating the double-phase medium. After 20 days, the same data as in Experiment 2 were recorded.

\section{Experimental Design}

The experiment was factorial, arranged in a Completely Randomized Design with ten repetitions in the Experiments 1 and 2, and five repetition per treatment in the Experiments 3,4 and 5, each repetition consisting of a flask with four explants. Results correspond to mean \pm standard deviation. For qualitative analysis of variance (ANOVA) and Tukey Test were performed at the $5 \%$ probability level $(p<0.05)$ and regression was applied for quantitative analysis. Statistical analyses were conducted using WinStat Statistical Analysis System version 2.0 (Machado \& Conceição 2005).

\section{RESULTS AND DISCUSSION}

Micropropagation has previously been evaluated as an alternative to vegetative propagation of Prunus rootstock (Cheong 2012), but the factors that influence success need to be optimized. Induction and proliferation of shoots in vitro are genetically determined (Silva et al. 2016). However, they can be limited by aspects of the physical and chemical microenvironment inside the flasks.In this context, our experiments aimed to study the factors that may affect the success of in vitro proliferation, since 'Flordaguard' rootstock remains recalcitrant (Arab et al. 2014). Hence, to evaluate the effect of these factors on shoot multiplication, five experiments were performed, as shown in Figure 1.

\section{Effect of culture medium on shoot proliferation}

When the effects of both the culture media were evaluated (Experiment 1) the number of shoots per explant was 1.8 -fold higher in the MS- $1 / 2 \mathrm{~N}$ medium $(2.80 \pm 0.76)$ than in the full MS medium (1.56 \pm 0.68$)$ (Tab. 1). When explants were transferred to the MS and MS- $1 / 2 \mathrm{~N}$ medium with $0.5 \mathrm{mg} \mathrm{L}^{-1} \mathrm{BAP}$ (Experiment 2), the number of lateral shoots were again evaluated and, as expected, there were no differences in relation to Experiment 1. However, at the end of Experiment 2, the number of lateral shoots elongated and the length of lateral shoots were higher in the MS- $1 / 2 \mathrm{~N}$ than in the full MS medium (Tab. 1). 


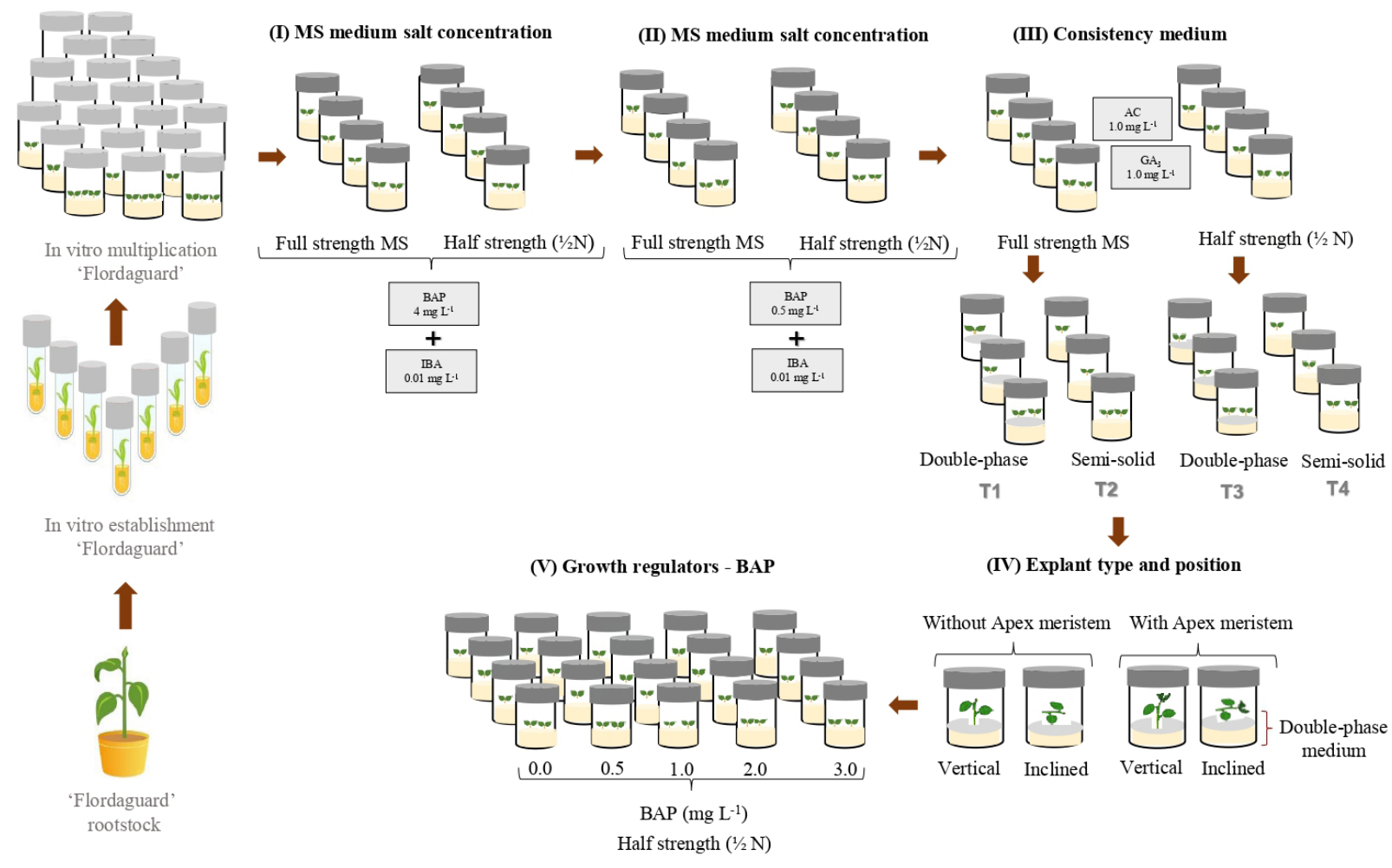

Figure 1. Order of the factors tested for improvement in the in vitro multiplication of 'Flordaguard' peach rootstock. I. Salt medium composition in $4 \mathrm{mg} \mathrm{L}^{-1}$ BAP; II. Salt medium composition in $0.5 \mathrm{mg} \mathrm{L}^{-1} \mathrm{BAP}$; III. Culture medium consistency; IV. Explant type and position; and V. Explant growth in half strength MS medium with different BAP doses.

Table 1. Shoot proliferation from node explant of 'Flordaguard' peach rootstock cultivated for 30 days in MS and MS-1/2 N medium supplemented with $4 \mathrm{mg} \mathrm{L}^{-1} \mathrm{BAP}$ (Experiment 1) and $0.5 \mathrm{mg} \mathrm{L}^{-1} \mathrm{BAP}$ (Experiment 2).

\begin{tabular}{ccccc}
\hline \multirow{2}{*}{ Medium strength } & \multicolumn{2}{c}{ Experiment 1} & \multicolumn{3}{c}{ Experiment 2} \\
& $\mathrm{~N}^{\mathrm{o}}$ lateral shoots* & $\mathrm{N}^{\mathrm{o}}$ lateral shoots* & $\mathrm{N}^{\mathrm{o}}$ lateral shoots elongated* & Length of lateral shoots $(\mathrm{cm}){ }^{*}$ \\
\hline MS- 1 - $2 \mathrm{~N}$ & $2.80 \pm 0.76 \mathrm{a}$ & $2.88 \pm 0.32 \mathrm{a}$ & $0.40 \pm 0.13 \mathrm{a}$ & $0.40 \pm 0.13 \mathrm{a}$ \\
$\mathrm{MS}$ & $1.56 \pm 0.68 \mathrm{~b}$ & $1.55 \pm 0.46 \mathrm{~b}$ & $0.18 \pm 0.08 \mathrm{~b}$ & $0.25 \pm 0.08 \mathrm{~b}$ \\
$\mathrm{CV}(\%)$ & 32.66 & 20.12 & 51.54 & 45.38 \\
\hline
\end{tabular}

Values represent mean \pm standard deviation of 10 replicates (flasks with four explants)

Mean values followed by different letters in the column differ significantly by Tukey test $\mathrm{P} \leq 0.05$.

*per initial explant

6-benzylaminopurine (BAP); coefficient of variation (CV); Murashige and Skoog (MS)

In Experiment 3 the number of lateral shoots per explant was ca. 1.8 fold higher when the explants were cultivated in semi-solid $\mathrm{N}^{-1} \frac{1}{2} \mathrm{~N}$ with $\mathrm{AC}+\mathrm{GA}_{3}(3.25 \pm 0.90)$ than in both the full MS media. On the other hand, the explants subcultured in full MS medium with $\mathrm{AC}+\mathrm{GA}_{3}$ showed shoots, but they did not elongate significantly, showing a clear decline in shoot formation, after the third subculture in such condition. In spite of the higher number of elongated shoots per explant observed in MS $(1 / 2 \mathrm{~N})$ double-phase, no differences were observed in relation to shoots in the full MS double-phase (Tab. 2). Theses results demonstrate that the addition of liquid medium over the semi-solid medium contributes to reduce the decline in shoot formation and elongation over the the repeated subcultures in full MS medium.
Culture medium plays an important role in the process of in vitro propagation and its optimization is essential because macro- and micronutrient content influences shoot induction, elongation, and multiplication (Phillips \& Garda 2019). Indeed, it is challenging to adjust the appropriate culture medium to develop a particular species, especially for woody plants. Choice of culture medium can be quite complex because the response is genotype-dependent and the effects of mineral nutrition on morphogenesis have scarcely been studied (Arab et al. 2014). The most commonly used basal medium is Murashige and Skoog (MS) and modified MS (mMS) at different strengths of mineral content $\left(1 / 2 \mathrm{MS}, \mathrm{MS}^{3} / 4\right.$, and $\left.1 / 2 \mathrm{~N}\right)$. MS medium has a high concentration of ammoniacal nitrogen $\left(\mathrm{NH}_{4}^{+}\right)$in comparison with the majority of other media (Phillips \& 
Table 2. Number of lateral shoots, lateral shoots elongated, and average length of lateral shoots of 'Flordaguard' peach rootstock cultivated for 20 days in MS andMS-1/2N medium supplemented with $0.5 \mathrm{mg} \mathrm{L}^{-1} \mathrm{BAP}, 0.01 \mathrm{mg} \mathrm{L}^{-1} \mathrm{IBA}_{1} 1 \mathrm{mg} \mathrm{L}^{-1} \mathrm{GA}_{3}$ and $1 \mathrm{~g} \mathrm{~L}^{-1} \mathrm{AC}$ isolated or in combination with liquid medium (LM) contained $\mathrm{MS}-1 / 2 \mathrm{~N}$ medium and $1 \mathrm{mg} \mathrm{L}^{-1} \mathrm{GA}_{3}$ and $1 \mathrm{~g} \mathrm{~L}^{-1} \mathrm{AC}$.

\begin{tabular}{|c|c|c|c|c|}
\hline Medium Strength & Medium consistency & $\mathrm{N}^{\mathrm{o}}$ lateral shoots* & $\mathrm{N}^{\mathrm{o}}$ lateral shoots elongated* & Length of lateral Shoots* $(\mathrm{cm})$ \\
\hline $\mathrm{MS}-1 / 2 \mathrm{~N}+\mathrm{LM}$ & Double-phase & $2.83 \pm 0.46 \mathrm{ab}$ & $0.96 \pm 0.08 \mathrm{a}$ & $1.80 \pm 0.41 \mathrm{a}$ \\
\hline $\mathrm{MS}-1 / 2 \mathrm{~N}$ & Semi-solid & $3.25 \pm 0.90 \mathrm{a}$ & $0.53 \pm 0.19 b$ & $0.94 \pm 0.17 \mathrm{~b}$ \\
\hline $\mathrm{MS}+\mathrm{LM}$ & Double-phase & $1.76 \pm 0.32 \mathrm{~b}$ & $0.61 \pm 0.20 \mathrm{~b}$ & $1.54 \pm 0.27 \mathrm{a}$ \\
\hline MS & Semi-solid & $1.80 \pm 0.57 \mathrm{~b}$ & $0 \pm 0 \mathrm{c}$ & $0 \pm 0 \mathrm{c}$ \\
\hline $\mathrm{CV}(\%)$ & & 25.01 & 28.01 & 27.91 \\
\hline
\end{tabular}

Values represent mean \pm standard deviation of 5 replicates (flasks with four explants)

Mean values followed by different letters in the column differ significantly by Tukey test $\mathrm{P} \leq 0.05$.

* per initial explant

Activated charcoal (AC); 6-benzylaminopurine (BAP); coefficient of variation (CV); Murashige and Skoog (MS), gibberellic acid (GA ${ }_{3}$ )

Garda 2019). In the current study differences in the number of shoots were evident, and they were around 1.5 to 1.8 fold higher in the MS- $1 / 2 \mathrm{~N}$ medium (Figs. 2A, D) than in the full MS medium (Figs. 2B and 2C), in Experiments 1,2 , and 3 .

Reducing the nitrogen concentration in MS- $1 / 2 \mathrm{~N}$ medium led to an enhanced response in terms of shoot proliferation. It seems that the higher amount of nitrogen in full strength MS medium, compared to MS- $-1 / 2 \mathrm{~N}$ medium, inhibits explant growth and induces a strong decline in the 'Flordaguard' shoots after the first three subcultures. Many researchers have reported that $\mathrm{NH}_{4}^{+}$plays a key role in the in vitro culture of Prunus rootstock but that it can be harmful at high concentrations (Ivanova \& Van Staden, 2009). Studies by Arab et al. (2014) showed that the $\mathrm{NH}_{4} \mathrm{NO}_{3}$ and $\mathrm{KNO}_{3}$ in the full MS medium were inadequate for optimal growth and multiplication of $\mathrm{G} x \mathrm{~N} 15$ rootstock. Furthermore, plants of the Rosaceae family tend towards sensitivity, and $\mathrm{NH}_{4}^{+}$may produce toxicity (Britto \& Kronzucker 2002).

Nitrogen sources and concentrations alter the development pattern of explants and affect the response of each cultivar (Silvestri et al. 2019). Some species and/ or cultivars may have better responses to full strength MS media, such as apple (Samanmalie et al. 2019) and papaya (Saadala et al. 2012). However, while aiming at better plant development and reduction in costs, several authors have suggested the possibility of reducing the salt concentration of MS medium for various woody plants (Ivanova \& Van Staden 2009, Silvestri et al. 2019). It is challenging to cut down the cost of production per plant using so-called "low-cost tissue culture" and our findings indicate that the choice of medium, and especially its concentration, could be a powerful lever to successfully manage this process.

Independent of the medium, MS- $1 / 2 \mathrm{~N}$ or MS, the highest shoot lengths were observed in the double-phase medium in the presence of $\mathrm{AC}+\mathrm{GA}_{3}$. The best responses observed in double-phase medium may have been due to higher nutrient availability, as nutrients and growth regulators are more easily absorbed by shoots in liquid medium (Stevens
\& Pijut 2018). Another advantage of the double-phase system is reduction in manipulation during the in vitro multiplication stages, since there is no need to perform constant subculturing, resulting in reduced expenses in growth medium gelling agents (Scherwinski-Pereira $e t$ al. 2012), which represents about $60-70 \%$ of the medium costs in Brazil. The higher rate of shoot growth obtained in double-phase medium may be related to the wider contact of the tissue with the medium, as shown in Figs. 3A and 4B. The double-phase culture medium is widely used in in vitro culture systems as it is more efficient for many species such as pear rootstock (Moraes et al. 2004), and apple rootstock (Machado et al. 2004).

Surakshitha et al. (2019) reported that the major physiological disorder observed during in vitro culture of woody plant species is shoot-tip necrosis (STN). Besides STN we also observed severe hyperhydricity in the explants and leaf yellowing, mainly in full strength MS, which resulted in a significantly reduction in the multiplication index per explant (Figs. 4A and 4B). Nutrient deficiencies and excesses can result in negative impacts and physiological and morphological disorders, such as STN and hyperhydricity or vitrification (Ivanova \& Van Staden, 2009). Similar trends have previously been reported in peach rootstock $\mathrm{G} \times \mathrm{N} 9$ (Radmann et al. 2009b) and G $x$ N15 (Arab et al. 2014). STN has been studied in grape cultivar "Red Globe" by Surakshitha et al. (2019), and they verified that growing the cultures in half strength MS media supplemented with higher calcium content, and reducing BAP and the subculture intervals, could significantly reduce the incidence of STN in the explants. Added to these factors that influence explant growth, the ethylene concentration inside the culture flasks is known to be involved in leaf yellowing, inhibition of shoot formation, and the senescence of plants (Marino \& Ventura 1997). In an attempt to reduce the undesirable effects of ethylene, Park et al. (2016) showed that the use of ethylene-inhibiting agents was beneficial for apical shoot initiation and to reduce leaf yellowing in rose cultivar "Tineke". 


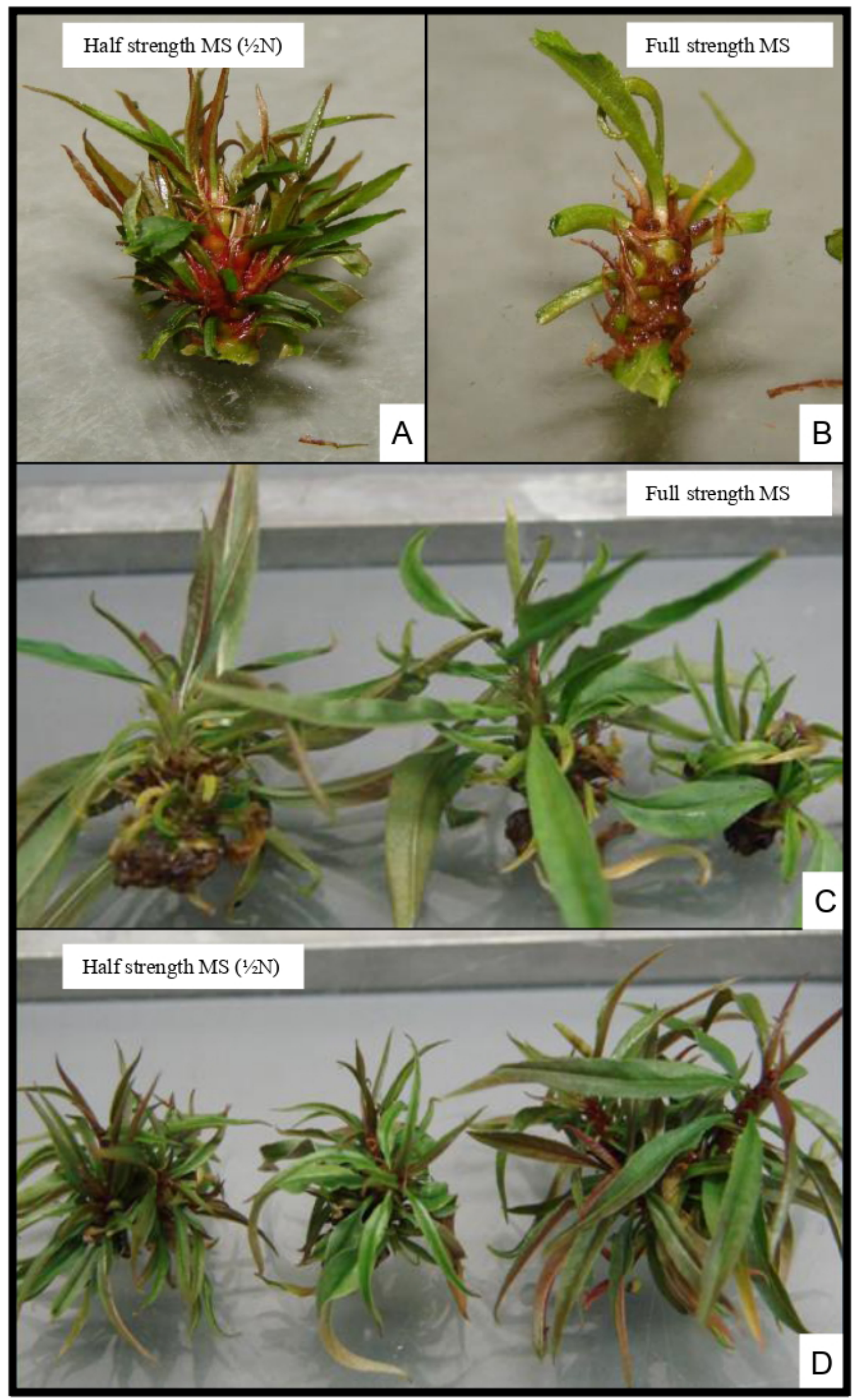

Figure 2. Shoot proliferation from node explant of 'Flordaguard' peach rootstock. A. Shoot cultured in half strength MS (1/2N); B. full strength MS medium; C. Induction of multiple shoots in full strength MS supplemented with $0.5 \mathrm{mg} \mathrm{L}^{-1}$ of BAP; D. induction of multiple shoots in half strength MS $\left(1 \frac{1}{2} \mathrm{~N}\right)$ supplemented with $0.5 \mathrm{mg} \mathrm{L}^{-1}$ of BAP. 


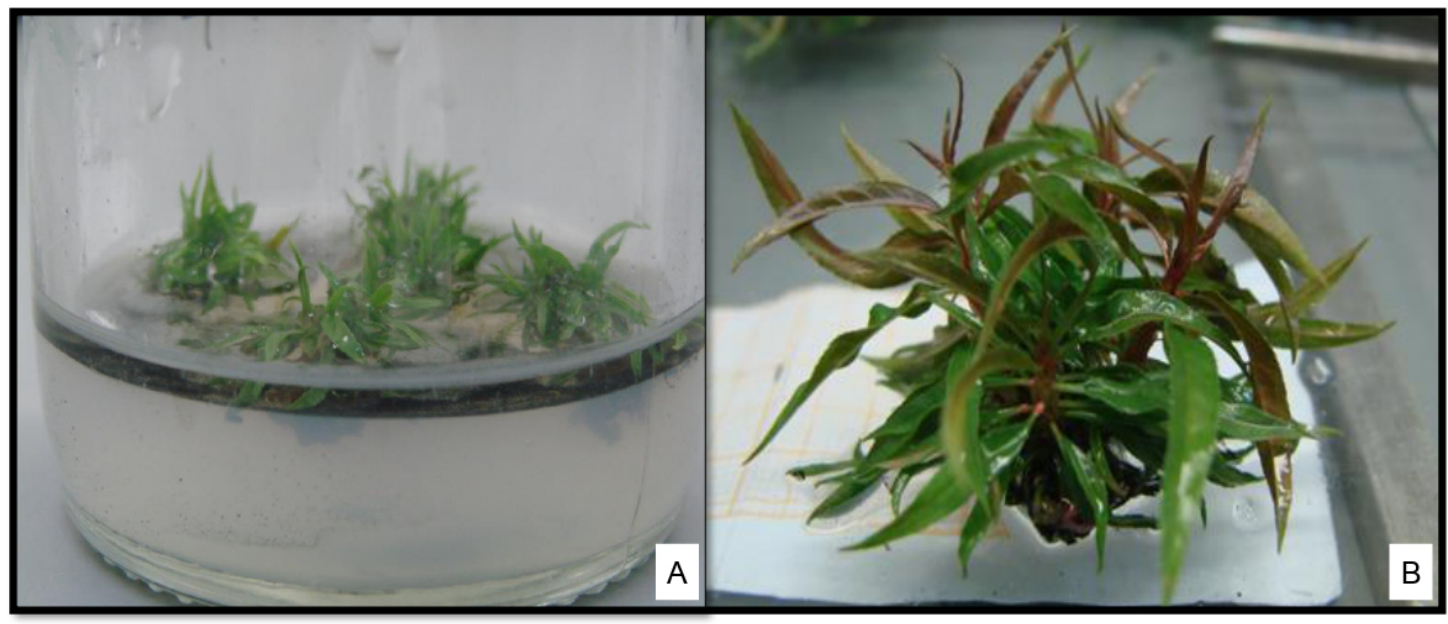

Figure 3. Shoot proliferation in 'Flordaguard' peach rootstock. A. Induction of multiple shoot in explants cultured in half strength MS (1/2N) containing $1.0 \mathrm{mg} \mathrm{L}^{-1}$ of $\mathrm{GA}_{3}$ and $1.0 \mathrm{~g} \mathrm{~L}^{-1}$ of activated charcoal (double-phase medium); B. Growth and development of isolated shoots after 20 days in double-phase medium.

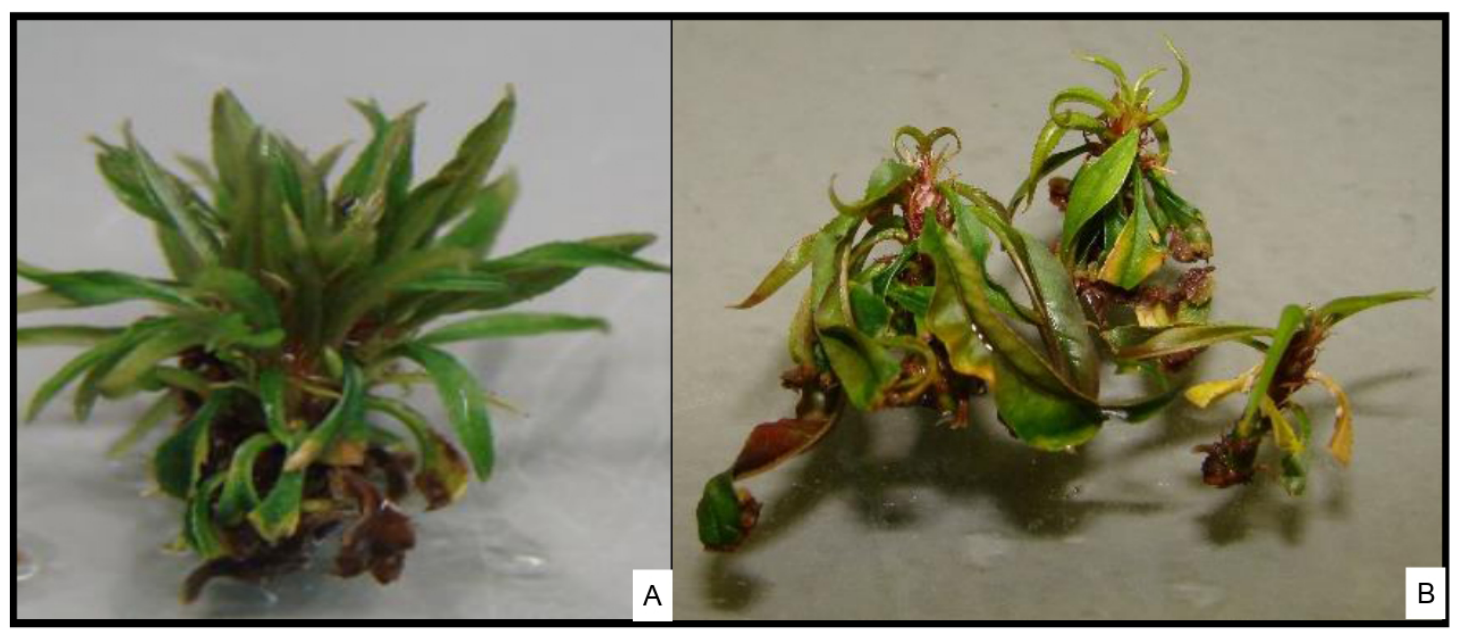

Figure 4. Shoots proliferation from node explant of 'Flordaguard' peach rootstock cultured on full strength MS medium. A. Growth and development of isolated shoot with symptoms of hyperhydricity; B. Growth and development of multiple shoot with shoot-tip necrosis (STN).

\section{Effect of explant type and the angle of inoculation on shoot induction and proliferation}

For the number of shoots per explant, an isolated effect of the factors was observed, with greater response for explants without the apical portion and inoculated at a $45^{\circ}$ angle, $4.58 \pm 0.46$ and $4.40 \pm 0.49$ shoots, respectively (Tab. 3). The number of elongated shoots was influenced only by the factor explant type; the better response verified with explants without the apical portion $(3.22 \pm 0.34)$. However, as regards shoot length there was no significant difference, obtaining as a general average $0.93 \mathrm{~cm}$ (data not shown).

According to the results of the previous experiments, shoot induction and proliferation were more effective in MS- $1 / 2 \mathrm{~N}$ medium, which was the medium used in subsequent experiments. In the current study, the best average number of shoots per explant was observed in explants without the apical portion (apical meristem removed). Likewise,
George et al. (2008) reported that simple decapitation of shoots allowed the production of new axillary shoots and increased the multiplication rate. These results can be explained by the apical dominance being broken, because high concentrations of auxin at the apical meristem of explants inhibits the growth of lateral buds and decreases the cytokinin/auxin ratio. In contrast, for apple cv. MM111 , no significant effect was observed between explants with or without apical portion (Pereira \& Fortes, 2001).

The comparison between the angle inclined $\left(45^{\circ}\right)$ and vertical $\left(90^{\circ}\right)$ explants inoculation showed visible differences. Inclined explants produced an increased number of shoots. Similar to our results, the superiority of the number of shoots in inclined explants has been reported by Radmann et al. (2009a). A factor to be considered here is the polar transport of auxins, since translocation is limited or inhibited when the explants are cultured at an inclined angle, resulting in higher multiplication index. 
Table 3. Number of shoots per explant (explant type and explant angle) and number elongated shoots (explant type and explant angle) obtained with 'Flordaguard' peach rootstock, grown for 30 days in MS- $-1 / 2 \mathrm{~N}$ medium with $3.0 \mathrm{mg} \mathrm{L}^{-1}$ BAP and 20 days in double-phase medium.

\begin{tabular}{ll}
\hline Explant type & $\mathrm{N}^{\circ}$ shoots per explant \\
\hline Without apical portion & $4.58 \pm 0.46 \mathrm{a}$ \\
With apical portion & $3.77 \pm 0.30 \mathrm{~b}$ \\
\hline $\mathrm{CV}(\%)$ & 8.68 \\
\hline Explant angle in the medium & $\mathrm{N}^{\circ}$ shoots per explant \\
\hline Inclined $\left(45^{\circ}\right)$ & $4.40 \pm 0.49 \mathrm{a}$ \\
Vertical $\left(90^{\circ}\right)$ & $3.95 \pm 0.55 \mathrm{~b}$ \\
\hline $\mathrm{CV}(\%)$ & 12.68 \\
\hline Explant type & $\mathrm{N}^{\circ}$ elongated shoots per explant \\
\hline Without apical portion & $3.22 \pm 0.34 \mathrm{a}$ \\
With apical portion & $2.63 \pm 0.47 \mathrm{~b}$ \\
\hline CV $(\%)$ & 14.11 \\
\hline
\end{tabular}

Values represent mean \pm standard deviation of 10 replicates

Mean values followed by different letters in the column differ significantly to explant type and orientation by Tukey test $\mathrm{P} \leq 0.05$.

6-benzylaminopurine (BAP); coefficient of variation (CV); $\mathrm{MS}-1 / 2 \mathrm{~N}$ medium (Murashige and Skoog medium containing half the total $\mathrm{NH}_{4} \mathrm{NO}_{3}$ and $\mathrm{KNO}_{3}$ )

The growth of shoots during the multiplication phase is a determining variable in the quality of the material destined for subcultures and for the rooting phase (Radmann et al. 2009a). According to Rocha et al. (2009) shoots that present shorter length cannot be cultured directly in rooting media. The results did not show significance for shoot length and, additionally, a reduced growth of shoots was observed (less than $1.0 \mathrm{~cm}$ ). In the light of this result, it became necessary to study the effect of other factors that may be involved in the success of multiplication and elongation. Therefore, the fifth experiment was conducted to evaluate the effect of different BAP concentrations on shoot proliferation.

\section{Effect of BAP concentration on shoot proliferation}

In vitro propagation of the Prunus genus shows some progress (Cheong 2012), however, the choice of cytokinins, in terms of source and concentration retains a critical role (Vujovic et al. 2012). The presence of cytokinin in the medium is essential for shoot proliferation, as well as subsequent rooting and acclimation of plantlets (Kassaye $\&$ Bekele 2015). Among cytokinins, BAP costs the least and is the most commonly-used product for inducing cell division and shoot development (Ashraf et al. 2014). In this context, to optimize in vitro shoot proliferation of 'Flordaguard' rootstock, five concentrations of BAP were tested $\left(0.5\right.$ to $\left.3.0 \mathrm{mg} \mathrm{L}^{-1}\right)$.

The addition of BAP to the culture medium resulted in a trend in all surveyed variables. Regarding the number of shoots, a quadratic response was obtained, with a maximum point at $2.39 \mathrm{mg} \mathrm{L}^{-1} \mathrm{BAP}$ producing of 3.30 shoots per explant (Fig. 5A). However, in absolut values, it was found that the use of $3.0 \mathrm{mg} \mathrm{L}^{-1} \mathrm{BAP}$ induced the best responses, with the formation of 3.38 shoots per explant. For the number of elongated shoots, the maximum value estimate by the regression equation was 2.05 shoots elongated with $1.98 \mathrm{mg} \mathrm{L}^{-1}$ BAP (Fig. 5B). Concerning the length of shoots, the maximum estimated values occurred at $1.82 \mathrm{mg} \mathrm{L}^{-1} \mathrm{BAP}$ with length of $1.03 \mathrm{~cm}$ (Fig. 5C). This result was not much better than that found when $3.0 \mathrm{mg}$ $\mathrm{L}^{-1} \mathrm{BAP}(0.74 \mathrm{~cm})$ was utilized.

When explants were cultivated in hormone-free media we did not observe significant responses for any of the evaluated variables. The positive effect of BAP was obtained in the other treatments $\left(0.5\right.$ to $\left.3.0 \mathrm{mg} \mathrm{L}^{-1} \mathrm{BAP}\right)$, mainly in relation to the number of shoots per explant at the highest concentration evaluated, producing more than three-fold the values obtained in the absence of this PGR. Similarly, Radmann et al. (2011) found a linear response, with about 2.5 shoots per explant, using $3.0 \mathrm{mg} \mathrm{L}^{-1} \mathrm{BAP}$ on 'Flordaguard' rootstock. In another study, Rodrigues et al. (2003) obtained about 2.0 shoots per explant, with $0.7 \mathrm{mg} \mathrm{L}^{-1} \mathrm{BAP}$ for 'Aldrighi', 'Eldorado', 'GF 677', and 'Okinawa' peach cultivars.

The lower cytokine requirement of certain genotypes may actually be associated with high endogenous levels, which, combined with exogenous cytokine addition to the culture medium, may contribute to reducing the
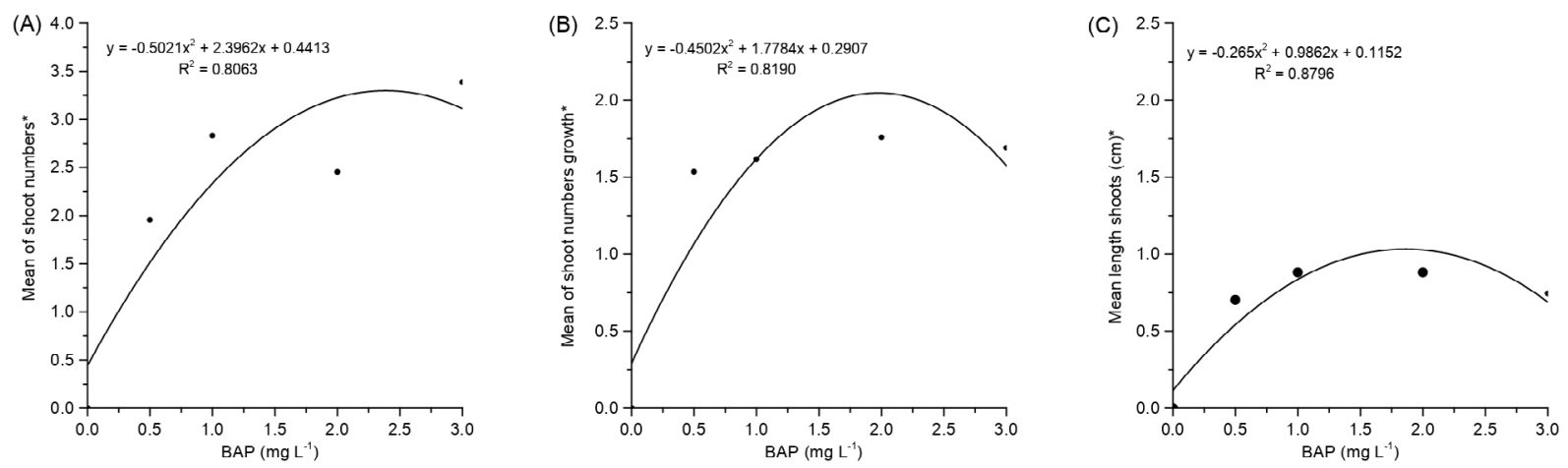

Figure 5. Shoots proliferation from node explant of 'Flordaguard' peach rootstock cultured in semi-solid MS- $1 / 2 \mathrm{~N}$ (without PGR). A. Mean number of shoots per explant; B. number of elongated shoots; C. and mean length of shoots obtained in half strength MS ( $1 / 2 \mathrm{~N})-$ double-phase under different concentrations of BAP $\left(0.5-3.0 \mathrm{mg} \mathrm{L}^{-1}\right)$ for 'Flordaguard' peach rootstock. 
multiplication rate and a rapid explant decline over subcultures. This type of effect has been observed in the in vitro multiplication of some plum genotypes (Rocha et al. 2009). Despite the good results achieved in shoot proliferation, shoot length was below the expected value, with about $1.31 \mathrm{~cm}$. This phenomenon seems to be a common feature in many species and cultivars of the genus Prunus (Radmann et al. 2009b). On the other hand, Leontiev-Orlov et al. (2000) obtained shoots of up to 6.8 $\mathrm{cm}$ for plum cultivars. This result reinforces the reports found in the literature that peach cultivars are more difficult to cultivate in vitro than plums.

Thus, even with the results obtained under the conditions tested in the present study with the 'Flordaguard' rootstock, this system needs to be validated for other genotypes due to the variability in multiplication responses observed in Prunus spp. In any event, further investigations are necessary since the results obtained concerning the number of shoots per explant, and especially those for shoot length are also critical to mass propagation.

Overall, our results showed that shoots of 'Flordaguard' rootstock can be more efficiently induced and proliferated in MS- $-1 / 2 \mathrm{~N}$ medium (BAP $3.0 \mathrm{mg} \mathrm{L}^{-1}$ ). Additionally, the double-phase medium culture favours the growth of shoots and explants without the apical portion and positioned with an inclined angle improve in vitro proliferation. The approach for optimization of culture medium by using salts, explant type, and the angle of explant inoculation in the medium as factors, as well as medium consistency, proved to be a useful tool for basic and applied research. Moreover, this study indicates the factors that positively affect the in vitro shoot proliferation of 'Flordaguard' explants, and that can be beneficial for in vitro propagation of other Prunus species and/or cultivars.

\section{ACKNOWLEDGEMENT}

The authors gratefully acknowledge the Conselho Nacional de Desenvolvimento Científico e Tecnológico (CNPq) for their financial support and also the Fundação de Amparo a Pesquisa do Estado do Rio Grande do Sul (FAPERGS). This study was financed in part by the Coordenação de Aperfeiçoamento de Pessoal de Nível Superior-Brazil (CAPES) - Finance Code 001.

\section{REFERENCES}

Abbasi, F., Khadivi, A., Taghizadeh, M. \& Valizadehkaji, B. 2019. Micropropagation of Prunus scoparia, a suitable rootstock for almond under drought conditions. International Journal of Fruit Science 19:221-230. https://doi.org/10.1080/15538362.2018.1539695

Arab, M.M., Yadollahi, A., Shojaeiyan, A., Shokri, S. \& Ghojahs, M. 2014. Effects of nutrient media, different cytokinin types and their concentrations on in vitro multiplication of $\mathrm{G} \times \mathrm{N} 15$ (hybrid of almond $\chi$ peach) vegetative rootstock. Journal of Genetic Engineering and Biotechnology 12:81-87. https://doi.org/10.1016/j.jgeb.2014.10.001

Ashraf, M.F., Aziz, M.A., Kemat, N. \& Ismaili, I. 2014. Effect of cytokinin types, concentrations and their interactions on in vitro shoot regeneration of Chlorophytum borivilianum Sant. \& Fernandez.
Electronic Journal of Biotechnology 17: 275-279. https://doi. org/10.1016/j.ejbt.2014.08.004

Britto, D.T. \& Kronzucker, H.J.2002. $\mathrm{NH}^{4+}$ toxicity in higher plants: a critical review. Journal Plant Physiology 159: 567-584. https://doi. org/10.1078/0176-1617-0774

Cheong, E.J. 2012. Biotechnological approaches for improvement and conservation of Prunus species. Plant Biotechnology Reports 6:1728. https://doi.org/10.1007/s11816-011-0195-y

Duval, H., Hoerter, M., Polidori, J., Confolent, C. \& Masse, M. 2013. High-resolution mapping of the RMia gene for resistance to root-knot nematodes in peach. Tree Genetics \& Genomes. https://doi.10.1007/ s11295-013-0683-z

George, E.F., Hall, M.A. \& Klerk, G.J.D. 2008. The components of plant tissue culture media I: macro- and micro-nutrients. In: George EF, Hall MA, Klerk GJD (eds) Plant propagation by tissue culture. Springer, Dordrecht, pp 65-113.

Hassan, S.A.M. \& Zayed, N.S. 2018.Factor Controlling Micropropagation of Fruit Trees: A Review. Science International 6:1-10. https:// doi.10.17311/sciintl.2018.1.10

Ivanova, M. \& Van Staden,J. 2009. Nitrogen source, concentration, and $\mathrm{NH}_{4}: \mathrm{NO}_{3}$, ratio influence shoot regeneration and hyperhydricity in tissue cultured Aloe polyphylla. Plant Cell, Tissue Organ Culture 99:167-174. https:// doi.1007/s11240-009-9589-8

Kadota, M., Imizu, K. \& Hirano, T. 2001. Double-phase in vitro cultureusing sorbitol increases shoot proliferation and reduceshyperhydricity in Japanese pear. Scientia Horticulturae 89: 207-215.

Kassaye, E. \& Bekele, B.D. 2015.In vitro optimization of the protocol for micropropagation of plum (Prunus salicina L. Var. methley) from nodal explants. Biotechnology International 8:137-148.

Leontiev-Orlov, O., Rogalski, M., Mossi, A.J. \& Cansian, R.L. 2000. 6-Benzilaminopurina (BAP) na multiplicação in vitrode prunáceas (Prunussp.). Revista Brasileira de Agrociência6: 63-67. http://dx.doi. org/10.18539/cast.v6i1.306

Loreti, F. \& Massai, R. 1999. I portinnesti del pesco. L'Informatore Agrario (Supplemento) $6: 39-44$.

Machado, A.A. \& Conceição, A.R. 2005. WinStat - sistema de análise estatística para Windows. Versão Beta. Pelotas: Universidade Federal de Pelotas.

Machado, M.P., Carvalho, D.C. \& Biasi, L.A. 2004.Multiplicação in vitrodo porta-enxerto de macieira 'Marubakaido' em diferentes meios de cultivo e concentrações de ácido giberélico. Scientia Agraria 5:69-72. http://dx.doi.org/10.5380/rsa.v5i1.1099

Marino, G. \& Ventura, M. 1997. The influence of ethylene on in vitro rooting of GF 677 (Prunus persica $\times$ Prunus amygdalus) hybrid peach rootstock. In Vitro Cellular \& Developmental Biology - Plant 33: 26-29. https://doi.org/10.1007/s11627-997-0036-4

Mayer, N.A., Bianchi, V.J., Feldberg, N.P. \& Morini, S. 2017. Advances in peach, nectarine and plum propagation. Revista Brasileira de Fruticultura 39:1-21. http://dx.doi.org/10.1590/0100-29452017355

Moraes, L.K.A., Felisbino, C., Crestani, L. \& Silva, A.L. 2004. Estabelecimento e multiplicação in vitro de Pyruscalleryana D-6 em sistema de cultura 'dupla-fase'. Revista Brasileira de Fruticultura 26:403-405. http://dx.doi.org/10.1590/S0100-29452004000300008

Murashige, T. \& Skoog, F. 1962. Arevised medium for rapid growth and biomassay with tobacco tissue cultures. PhysiologiaPlantarum 15:473-479.

Park, J.S., Naing, A.H. \& Kim, C.K. 2016. Effects of ethylene on shoot initiation, leaf yellowing, and shoot tip necrosis in roses. Plant Cell, Tissue and Organ Culture 127:425-431.

Phillips, G.C. \& Garda, M. 2019. Plant tissue culture media and practices: an overview. In Vitro Cellular \& Developmental Biology - Plant 55:242-257. https://doi.org/10.1007/s11627-019-09983-5

Pei, M., Gu, C. \& Zhang, S. 2019.Genome-wide identification and expression analysis of genes associated with peach (Prunus persica) fruit ripening. Scientia Horticulturae 246:317-327. https://doi. org/10.1016/j.scienta.2018.10.065

Pereira, J.E.S. \& Fortes, G.R.L. 2001.Multiplicação e aclimatização da macieira influenciada pelo tipo de explante e pelo tempo de permanência em meio de cultura de enraizamento. Revista Brasileira de Fruticultura 23:417-420. http://dx.doi.org/10.1590/S010029452001000200044 
Radmann, E.B., Bianchi, V.J., Oliveira, R.P. \& Fachinello, J.C. 2009a. Multiplicação in vitro e alongamento das brotações micropropagadasdo porta-enxerto 'Tsukuba 1' (Prunuspersica L.). RevistaBrasileira de Fruticultura 31:656-663. http://dx.doi. org/10.1590/S0100-29452009000300006

Radmann, E.B., Bianchi, V.J., Souza, T.J., Fachinello, J.C. \& Oliveira, R.P. 2009b.Influence of culture medium composition and explant type on micropropagation of the rootstock Prunus sp. ' $\mathrm{G} \times \mathrm{N}-9$ '. Scientia agraria 10:95-101.

Radmann, E.B., Bianchi, V.J., Fachinello, J.C., Ferreira, L.V. \& Oliveira, R.P. 2011. In vitro multiplication of 'Flordaguard' rootstock: cytokinin source and concentration effects, explants orientation and period of permanence in the cultive medium. Brazilian Archives of Biology and Technology 54:25-34. http://dx.doi.org/10.1590/ S1516-89132011000100004

Reighard, G. \& Loreti, F. 2008. Rootstocks development. p.193-220. In. LAYNE, D. and D. BASSI (eds.) The peach: Botany, production and uses. CABI Publishing, Wallingford, Oxon, UK.

Rocha, P.S.G., Schuch, M.W., Bianchi, V.J. \& Fachinelo, J.C. 2009. Multiplicação e alongamento in vitro do porta-enxerto de Prunus. BioscienceJournal 25:69-74. http://www.seer.ufu.br/index.php/ biosciencejournal/article/view/6793

Rodrigues, A.C., Silveira, C.A.P., Fortes, G.R.L., Fachinello, J.C. \& Silva, J.B. 2003. Estabelecimento e multiplicação in vitro de Prunus sp. em diferentes meios de cultura. Revista Brasileira de Fruticultura 25:131-133. http://dx.doi.org/10.1590/S0100-29452003000100037

Rodríguez, R., Díaz-sala, C., Cuozzo, L. \& Ancora, G. 1991. Pear invitro propagation using a double-phase culture system.HortScience 26: 62-64.

Saadala, M.M. \& Said, A.E.U. 2012. Effect of Medium Components on in vitro Shoot Formation and Rooting of Papaya (Carica papaya L.). The Journal of Agricultural Science 20:243-258.

Samanmalie, L.G.I., Rupasinghe, M.D.M. \& Weerasinghe, P.A. 2019. Tissue Culture Protocol for Production of Planting Materials of Apple by Using Shoot Tip Culture. International Research Journal of Advanced Engineering and Science 4:287-289. 10.1007/s12892011-0028-0

Sherman, W.B., Lyrene, P.M. \& Sharpe, R.H. 1991. Flordaguard peach rootstock. HortScience 26:427-428. https://doi.org/10.21273/ HORTSCI.26.4.427

Scherwinski-Pereira, J. E., Lima, E.C.A., Silva, T.L.S., Mesquita, A.G.G. \& Maciel, S.A. 2012.Double-phase culture system for large-scale production of pineapple. PlantCell, Tissue OrganicCulture 109:263269. https://doi.10.1007/s11240-011-0091-8

Silvestri, C., Rugini, E. \& Cristofori, V. 2019.The effect of $\mathrm{CuSO}_{4}$ for establishing in vitro culture, and the role nitrogen and iron sources in invitro multiplication of Corylus avellana L. cv. Tonda Gentile Romana. Plant Biosystems - An International Journal Dealing with all Aspects of Plant Biology. https://doi.10.1080/11263504.2018 .1549610

Silva, I.M.C., Cuchiara, C.C., Winhelmann, M.C., Bianchi, V.J. \& Braga, E.J.B. 2016. Multiplicação in vitro de pereira cultivar Cascatense. Semina: Ciências Agrárias 37:581-594. https://doi.10.5433/16790359.2016v37n2p581

Surakshitha, K., Soorianathasundaram, S.K., Ganga, M. \& Raveendran, M. 2019. Alleviating shoot tip necrosis during in vitro propagation of grape cv. Red Globe. Scientia Horticulturae 248: 118-125. https:// doi.10.1016/j.scienta.2019.01.013

Stevens, M.E. \& Pijut, P.M. 2018. Rapid in vitro shoot multiplication of the recalcitrant species Juglans nigra L. In Vitro Cellular \& Developmental Biology - Plant 54:309-317. https://doi.org/10.1007/ s11627-018-9892-3

Viganó, C.R.; Bianchi, V.J., Rocha, P.S.G., Schuch, M.W. \& Fachinello, J.C. 2007. Enraizamento in vitro do porta-enxerto de Prunus cv. Mr. S. 1/8: concentrações de IBA em meio de cultura acrescido de ágar ou vermiculita. Bioscience Journal 23: 60-65.

Vujovic, T., Ruzic, D. \& Cerovic, R. 2012. In vitro shoot multiplication as influenced by repeated subculturing of shoots of contemporary fruit rootstocks. Horticulturae Science 39:101-107. http://dx.doi. org/10.17221/208/2011-HORTSCI 